ISSN: 2302-8556

E-Jurnal Akuntansi Universitas Udayana

Vol.24.3.September (2018):1880-1907

DOI: https://doi.org/10.24843/EJA.2018.v24.i03.p09

\title{
Pengaruh E-Commerce dan Efektivitas Kerja Pengguna terhadap Kinerja Perusahaan Pada Usaha Kecil, Menengah Di Denpasar
}

\author{
Ni Made Werin Sarastyarini ${ }^{1}$ \\ I Ketut Yadnyana ${ }^{2}$ \\ ${ }^{1,2}$ Fakultas Ekonomi dan Bisnis Universitas Udayana, Bali, Indonesia \\ e-mail: werinsaras8610@ gmail.com
}

\begin{abstract}
ABSTRAK
Tujuan penelitian ini adalah untuk mengetahui pengaruh e-commerce dan efektivitas kerja pengguna terhadap kinerja perusahaanpada usaha kecil dan menengah di Denpasar. Populasi dalam penelitian ini adalah 766 UKM yang menggunakan e-commerce di Denpasar dan sampel yang diambil adalah 88 UKMyang menggunakan e-commerce di Denpasar. Sampel dalam penelitian ini ditentukan dengan metode probability sampling dengan teknik simple random sampling. Pengumpulan data dilakukan melalui survei yang diperoleh dengan cara penyebaran kuesioner kepada para responden. Responden dalam penelitian ini adalah para pelaku usaha. Teknik analisis yang digunakan regresi linier berganda (multiple linear regression) dengan software SPSS 22.0. Hasil penelitian menunjukkan bahwa kinerja perusahaan pada usaha kecil dan menengah akan semakin meningkat apabila pelaku usaha menggunakan e-commerce dalam menjalankan dan mengembangkan usahanyadan peningkatan pada efektivitas kerja pengguna $e$ commerce akan diikuti juga dengan peningkatan kinerja perusahaan pada usaha kecil dan menengah yang menggunakan e-commerce di Denpasar.
\end{abstract}

Kata kunci: E-Commerce, Efektivitas Kerja Pengguna, Kinerja Perusahaan

\begin{abstract}
The purpose of this study is to determine the effect of e-commerce and effectiveness of the user's work on the company's performance on small and medium enterprises in Denpasar. The population in this study were 766 SMEs using e-commerce in Denpasar and the samples taken were 88 SMEs using e-commerce in Denpasar. The sample in this research is determined by probability sampling method with simple random sampling technique. Data collection was done through survey obtained by distributing questionnaires to the respondents. Respondents in this study are business actors. Analytical technique used multiple linear regression with SPSS 22.0 software. The results showed that the performance of companies in small and medium enterprises will increase if the business actors using e-commerce in running and developing business and improvement on the effectiveness of e-commerce users will be followed also by improving the performance of companies in small and medium enterprises that use $e$ commerce in Denpasar.

Keywords: E-Commerce, User Work Effectiveness, Corporate Performance
\end{abstract}


Ni Made Werin Sarastyarini dan Ketut Yadnyana. Pengaruh...

\section{PENDAHULUAN}

Usaha Kecil, dan Menengah (UKM) mempunyai peran penting dan strategis bagi pertumbuhan ekonomi negara, baik negara berkembang maupun negara maju. Kemampuan UKM perlu diberdayakan dan dikembangkan secara terus menerus dengan berusaha mereduksi kendala yang dialami UKM, sehingga mampu memberikan kontribusi lebih maksimal terhadap peningkatan kesejahteraan masyarakat (Sutaryo, 2004:290). UKM menjadi tumpuan untuk menghasilkan nilai tambah, penciptaan lapangan kerja, dan sumber devisa. Tidaklah mengherankan jika UKM menjadi sektor yang eksotis sehingga menjadi bagian penting dari persaingan perdagangan internasional. Negara yang berhasil menjadi negara maju juga memiliki keberhasilan dalam memajukan sektor usaha kecil dan menengah.

Sebagaimana diatur dalam Undang-Undang Nomor 20 Tahun 2008 tentang Usaha Kecil dan Menengah maka Usaha Kecil didefinisikan sebagai usaha ekonomi produktif yang berdiri sendiri, yang dilakukan oleh orang perorangan atau badan usaha yang bukan merupakan anak perusahaan atau bukan cabang perusahaan yang dimiliki, dikuasai, atau menjadi bagian baik langsung maupun tidak langsung dari usaha menengah atau usaha besar yang memenuhi kriteria Usaha Kecil. Sedangkan Usaha Menengah didefinisikan sebagai usaha ekonomi produktif yang berdiri sendiri, yang dilakukan oleh orang perseorangan atau badan usaha yang bukan merupakan anak perusahaan atau cabang perusahaan yang dimiliki, dikuasai, atau menjadi bagian baik langsung maupun tidak langsung dengan usaha kecil atau usaha besar dengan 
ISSN: 2302-8556

E-Jurnal Akuntansi Universitas Udayana Vol.24.3.September (2018):1880-1907

jumlah kekayaan bersih atau hasil penjualan tahunan sesuai dengan kriteria yang diatur dalam Undang-Undang.

Dunia yang semakin canggih dan teknologi semakin berkembang. Perkembangan tersebut secara langsung maupun tidak langsung mempengaruhi sistem perdagangan, transaksi dan peredaran uang selama ini. Sebelumnya, transaksi secara tradisional dilakukan dari tangan ke tangan secara langsung, antara pembeli dan penjual bertatap muka, melakukan persetujuan dan akhirnya terjadi kesepakatan. Namun kini, dengan adanya kecanggihan teknologi komputer, semua keterbatasan sarana, jarak, dan waktu transaksi dapat teratasi dengan mudah.Di jaman era globalisasi UKM mendapat banyak persaingan dari perusahaan-perusahaan besar, untuk tetap bisa berkompetitif UKM seharusnya menggunakan Teknologi Informasi (TI) dalam tingkatan yang sesuai dengan ukuran perusahaan. Tanpa hal itu diyakini bahwa UKM akan tetap lemah dibandingkan dengan perusahaan besar dalam hal pemasaran, perdagangan, keterampilan manajerial, dan sebagainya.

TeknologiInformasi (TI) sebenarnya hadir sebagai penyelamat bagi UKM karena Teknologi Informasi (TI) memberikan peralatan yang dibutuhkan untuk operasional dan manajemen (Maksuod, 2003:50).Salah satu bentuk perdagangan melalui Teknologi Informasi (TI) adalah e-commercehanya dengan klik pelanggan bisa mendapatkan barang yang diinginkan, bisa mengetahui apa saja yang diinginkan dan dapat melakukan transaksi dengan siapa saja tanpa dibatasi waktu dan jarak. Indikasi keunggulan e-commerce tersebut pada kenyataanya belum dimanfaatkan 
Ni Made Werin Sarastyarini dan Ketut Yadnyana. Pengaruh...

secara maksimal oleh kebanyakan UKM di Denpasar dengan berbagai sebab. Secara umum e-commerce merupakan fenomena yang akrab dalam kegiatan bisnis sekarang. Sudah banyak perpindahan barang dan pelayanan jasa yang dilakukan dengan lebih mudah, banyak dan tentunya cepat melalui jaringan dunia maya ini. Kegiatan dalam e-commerce sebenarnya tidak mengharuskan para pemasok, agen dan produsen untuk membuat dan membangun website. Namun banyak cara yang dapat dilakukan untuk mencari dan menawarkan barang dan jasa selain dengan website antara lain dengan menggunakan situs pertemanan, blog dan situs lainnya.

Rainer dan Cigielski (2011:55) mengemukakan bahwa electronic commerce (e-commerce )menggambarkan proses membeli, menjual, mentransfer, atau bertukar produk, jasa, atau informasi melalui jaringan komputer, termasuk internet. Di Indonesia, fenomena e-commerce dikenal sejak tahun 1996 dengan munculnya situs http://www.sanur.com sebagai took buku online pertama. Dari sisi pemanfaatan peluang, setidaknya sampai saat ini e-commerce merupakan solusi efektif bagi para pengusaha khususnya pengusaha kecil dan menengah untuk menembus pasar global yang pada akhirnya akan meningkatkan daya saing ekonomi nasional.

E-commerce juga memungkinkan perusahaan untuk memperluas jangkauan bisnis mereka. Salah satu manfaat utama dari e-commerce adalah akses ke dan dari pasar global. E-commerce menghilangkan hambatan geografis beberapa perusahaan yang ingin melakukan perdagangan global. Munculnya kegiatane-commerce ini harus dapat diantisipasi dengan tepat dan baik agar tidak kehilangan peluang meraih kesempatan dalam era globalisasi, terutama di bidang ekonomi. Pengusaha 
ISSN: 2302-8556

E-Jurnal Akuntansi Universitas Udayana Vol.24.3.September (2018):1880-1907

kecil dan menengah di Indonesia merupakan sasaran pokok yang harus dibina dan didorong agar dapat memanfaatkan e-commerce, hal ini dikarenakan posisi UKM yang sangat strategis antara lain pada populasinya yang mencapai 2,1 juta unit usaha yang tersebar di seluruh nusantara dan menyerap 20 juta tenaga kerja. Selain itu kegiatan usahanya relatif tahan terhadap resesi ekonomi dan memiliki daya saing untuk menghasilkan produk di pasaran global.

Hal ini meningkatkan kemampuan perusahaan untuk menarik pelanggan baru, sehingga meningkatkan pasar dan profitabilitas mereka secara keseluruhan Khan dan Motiwalla (2002:503). Penelitian sebelumnya mengenai e-commerce dan kinerja perusahaan dikemukakan oleh Kraemer et al., (2002:250) mereka menyimpulkan bahwa meningkatnya kinerja perusahaan dalam pengembangan e-commerce. Penelitian lainnya mengenai hubungan antara e-commerce dan kinerja perusahaan dilakukan oleh Khan dan Motiwalla (2002:507) yang melakukan penelitian untuk menilai bagaimana pengaruh e-commerce terhadap kinerja keuangan perusahaan. Penelitian ini menganalisa laporan keuangan dari 45 perusahaan terbuka di Amerika Serikat yang mengimplementasikan e-commercedan mengalami peningkatan dalam kinerja perusahaan. Berbeda dengan hasil penelitian yang dilakukan oleh Hariadi (2013) dimana tidak ada pengaruh antara kebermanfaatan $e$-commerce terhadap niat pengguna e-commerce, dan Retnoningtyas (2012:153) dimana sikap (attitude toward using) tidak memengaruhi niat untuk menggunakan kembali (reintention to use) pada e-commerce. Annisa (2012:72) dalam penelitiannya yang berjudul "Pengaruh Perangkat Lunak Akuntansi dan E-commerce terhadap Kinerja Perusahaan Pada 
Ni Made Werin Sarastyarini dan Ketut Yadnyana. Pengaruh...

Usaha Mikro, Kecil dan Menengah" menyatakan bahwa variabel perangkat lunak akuntansi berpengaruh positif terhadap kinerja pada UMKM dengan indikator ROA dan ROS, variabel e-commerce berpengaruh negatif terhadap kinerja pada UMKM dengan indikator ROA dan e-commerce berpengaruh positif terhadap kinerja pada UMKM dengan indikator ROS. Hasil dari penelitian ini adalah sebagaian besar sampel perusahaan mengalami kenaikan kinerja keuangan setelah mengimplementasikan e-commerce dalam proses bisnisnya.

Selain e-commerce, kinerja perusahaan pada UKM juga dipengaruhi oleh efektifitas kerja. Efektivitas berasal dari kata efektif, yaitu suatu pekerjaan dikatakan efektif jika suatu pekerjaan dapat menghasilkan atau mencapai sasaran dan diselesaikan tepat pada waktunya sesuai dengan rencana yang telah ditetapkan. Argris dalam Tangkilisan (2005:139) mengungkapkan bahwa efektivitas adalah keseimbangan atau pendekatan optimal pada pencapaian tujuan, kemampuan, dan pemanfaatan tenaga manusia. Jadi konsep tingkat efektivitas menunjukkan pada tingkat jauh organisasi melaksanakan kegiatan atau fungi-fungsi sehingga tujuan yang telah ditetapkan dapat tercapai dengan menggunakan secara optimal alat-alat dan sumber-sumber yang ada. Salah satu faktor yang mempengaruhi tercapainya peningkatan efektivitas kerja pengguna/pegawai adalah dengan menumbuhkan motivasi. Menurut Gibson (1998:154) dalam Tjhai (2003:115) menyatakan bahwa kinerja perusahaan merupakan indikator tingkatan prestasi yang dapat dicapai dan mencerminkan keberhasilan manajer. Penelitian yang dilakukan Ariyanto (2007:146) penggunaan teknologi sistem informasi yang tepat yang kemudian dilengkapi dengan 
ISSN: 2302-8556

E-Jurnal Akuntansi Universitas Udayana Vol.24.3.September (2018):1880-1907

pemakai yang ahli menggunakannya akan dapat meningkatkan kinerja perusahaan serta kinerja individual bersangkutan. Berdasarkan pada uraian latar belakang diatas, maka penulis termotivasi dari penelitian yang dilakukan oleh Hariadi (2013:98) dimana tidak ada pengaruh antara kebermanfaatan e-commerce terhadap niat pengguna $e$-commerce dan penelitian yang dilakukan oleh Annisa (2012:72) dimana variabel dalam penelitiannya dapat untuk mengetahui bagaimana perkembangan perangkat lunak dan e-commerce terhadap kinerja perusahaan pada UMKM.

E-commerce memungkinkan perusahaan untuk memperluas jangkauan bisnis mereka. Salah satu manfaat utama dari e-commerce adalah akses ke dan dari pasar global (Efraim, 2000). E-commerce menghilangkan hambatan geografis beberapa perusahaan yang ingin melakukan perdagangan global. Akhirnya, media yang interaktif dan teknologi database dari internet juga memungkinkan adanya kesempatan bagi sebuah perusahaan untuk mempromosikan produk dan jasa (Senn, 2000). Hal ini meningkatkan kemampuan perusahaan untuk menarik pelanggan baru, sehingga meningkatkan pasar dan profitabilitas mereka secara keseluruhan (Khan et al., 2002).Penelitian yang dilakukan oleh Kim et al (2004) menyatakan bahwa nilai utilitarian pencarian informasi melalui internet, nilai herdonis pencarian informasi melalui internet, manfaat yang dirasakan dari belanja secara online memengaruhi niat pencarian informasi secara online. Venkat (2000) dan Kreamer et al (2002) menemukan hubungan yang positif dan signifikan antara e-commerce terhadap kinerja perusahaan, yaitu meningkatnya kinerja perusahaan dalam pengembangan $e$ commerce. Sutikno et al (2012) penerapan e-commerce mempunyai pengaruh positif 
Ni Made Werin Sarastyarini dan Ketut Yadnyana. Pengaruh...

dan signifikan terhadap kinerja individu dalam memperluas pemasaran usaha, sehingga kinerja peusahaan berkembang dan mendapatkan pembeli dari dalam maupun luar negeri. Selain itu, manfaat yang diperoleh dengan diterapkannya $e$ commerce dapat menjangkau biaya komunikasi antara pemilik usaha dan konsumen lebih cepat, murah dan dapat berperan penting dalam peningkatan kinerja perusahaan.E-commerce juga dapat meningkatkan kecepatan dan akurasi informasi serta dapat membantu menghemat biaya operasional kantor Al-Refaee (2012).Hasil penelitian yang dilakukan Sarigih et al (2013) menjelaskan bahwa ecommerce memberikan pengaruh positif dan signifikan kepada UMKM karena ecommerce memberikan keuntungan yang dapat meningkatkan kinerja UMKM. Berdasarkan hal tersebut, maka hipotesis yang dapat diajukan dalam penelitian ini adalah sebagai berikut:

$\mathrm{H}_{1}$ : E-commerce berpengaruh terhadap kinerja perusahaan.

Jumaili (2005) mengemukakan bahwa penggunaan teknologi dalam aplikasi informasi perusahaan hendaknya mempertimbangkan pemakai.Tidak jarang ditemukan bahwa teknologi yang diterapkan dalam aplikasi informasi sering tidak tepat atau tidak dimanfaatkan secara maksimal oleh individu pemakai aplikasi informasi, sehingga aplikasi informasi kurang memberikan manfaat dalam meningkatkan kinerja perusahaan.Efektivitas penggunaan atau pengimplementasian teknologi aplikasi informasi dalam suatu perusahaan dapat dilihat dari kemudahan pemakai dalam mengakses informasi, komunikasi bisnis, dan meningkatkan penjualan perusahaan.Jumlah sarana komputer dalam perusahaan juga sangat 
ISSN: 2302-8556

E-Jurnal Akuntansi Universitas Udayana Vol.24.3.September (2018):1880-1907

mempengaruhi pencapaian efektivitas penggunaan teknologi aplikasi informasi dalam perusahaan. Dengan demikian banyak fasilitas pendukung yang disediakan bagi pemakai, maka akan semakin memudahkan pemakai dalam mengakses informasi untuk memperluas market place perusahaan.Diharapkan dengan penggunaan teknologi aplikasi informasi, individu dari perusahaan atau organisasi yang merupakan pemakai aplikasi tersebut dapat mengakses dan berbagi informasi yang bermanfaat bagi perusahaan, konsumen dan masyarakat serta kinerja yang dihasilkan tentu akan meningkat.Penggunaan teknologi informasi dalam menunjang aplikasi informasi memberikan pengaruh terhadap hampir semua aspek dalam pengelolaan bisnis.Keberhasilan aplikasi informasi suatu perusahaan tergantung bagaimana aplikasi tersebut dijalankan, kemudahan aplikasi itu bagi para pemakainya, dan pemanfaatan teknologi yang digunakan.

Antasari (2015) dalam penelitiannya yang berjudul "Pengaruh Efektivitas Sistem Informasi Akuntansi dan Penggunaan Teknologi Informasi pada Kinerja Perusahaan dengan Kepuasan Kerja Sebagai Variabel Pemoderasi”. Dalam penelitian ini efektivitas sistem informasi akuntansi berpengaruh positif pada kinerja perusahaan, penggunaan teknologi informasi berpengaruh positif pada kinerja perusahaan sehingga meningkatnya kinerja perusahaan sangat berpengaruh dari keefektivitasan kerja dari pemakai atau pelaku kerja tersebut, kepuasan kerja tidak memoderasi pengaruh efektivitas sistem informasi akuntansi pada kinerja perusahaan. Asep (2006:57) dalam penelitiannya yang berjudul "Peranan Penerapan Sistem Komputerisasi terhadap Efektivitas Kerja Karyawan Pada Puslitbang Geologi 
Bandung”. Dalam penelitian ini menyatakan bahwa setelah diterpkannya system komputerisasi efektivitas kerja karyawan menjadi lebih efektif. Sebelumnya beberapa penelitian mengenai pengaruh efektivitas sistem informasi akuntansi tehadap kinerja karyawan menunjukkanefektivitas penerapan sistem informasiakuntansi berpegaruh positif signifikan terhadap kinerja karyawan.Oleh karena itu, hipotesis dalam penelitian ini adalah sebagai berikut:

$\mathrm{H}_{2}$ : Efektivitas kerja pengguna berpengaruh terhadap kinerja perusahaan.

\section{METODE PENELITIAN}

Peranan e-commerce dan efektivitas kerja pengguna bagi perusahaan yang paling nyata adalah semua pekerjaan akan lebih cepat dan akurat. Penerapan e-commerce dan efektivitas kerja pengguna yang efektif akan mengurangi biaya yang tidak diharapkan dan dapat meningkatkan fleksibilitas. E-commerce dan efektivitas kerja pengguna dapat diterapkan pada semua jenis usaha dan telah menjadi kebutuhan dasar mulai dari perusahaan kecil sampai perusahaan besar. Jadi, sudah saatnya setiap perusahaan menggunakanjasa pembuat program untuk mulai menerapkan $e$ commerce dan keefektivitasan kerja pengguna dari e-commerce tersebut agar dapat bersaing dengan perusahaan lain. Lokasi penelitian ini adalah usaha kecil dan menengahyang menggunakan e-commerce di Denpasar. Pemilihan usaha kecil dan menengah yang menggunakan e-commerce dilakukan dari sumber informasi melalui Dinas Perindustrian dan Perdagangan di Kota Denpasar yang beralamat di Jalan Mulawarman Lumintang Denpasar. 
ISSN: 2302-8556

E-Jurnal Akuntansi Universitas Udayana Vol.24.3.September (2018):1880-1907

Menurut Sugiyono (2014:38), objek penelitian merupakan suatu sifat dari objek yang ditetapkan oleh peneliti untuk dipelajari dan kemudian akan memperoleh kesimpulan. Objek yang digunakan dalam penelitian ini adalah e-commerce dan efektivitas kerja pengguna terhadap kinerja perusahaan pada usaha kecil dan menengah yang menggunakan e-commerce di Denpasar.

Variabel independen $(\mathrm{X})$ adalah suatu variabel yang mempunyai atau menjadi sebab perubahan atau timbulnya variabel terikat atau dependen Sugiyono (2014:59). Variabel independen dalam penelitian ini adalah e-commerce dan efektivitas kerja pengguna.E-Commerce adalah merupakan proses jual beli barang/jasa secara elektronik yang melibatkan transaksi dengan mengunakan internet, jaringan, dan teknologi digital lainnya. Pada penelitian ini e-commerce dijelaskan dengan variabel dummy. Variabel dummy adalah sebuah variabel yang memiliki dua atau lebih distict levels, yang dikodekan dengan angka 0 atau 1. Variabel dummy memungkinkan kita untuk menggunakan variabel nominal atau ordinal seperti variabel independen untuk menjelaskan, mengerti, atau memprediksi variabel dependen. Variabel dummy merupakan sebuah variabel yang digunakan untuk mengkuantitatifkan variabel yang bersifat kualitatif. Variabel e-commerce dalam penelitian ini diukur dengan menggunakan variable dummy karena agar lebih menghindari bias, sehingga tidak ada unsur bias dalam variabel e-commerce hanya membedakan sampel penelitian bagi yang menggunakan atau yang tidak menggunakan $e$-commerce.

Efektivitas merupakan sumber daya manusia, sarana dan prasarana yang digunakan pada jumlah yang telah ditentukan untuk menghasilkan barang atas jasa 
Ni Made Werin Sarastyarini dan Ketut Yadnyana. Pengaruh...

kegiatan yang dilaksanakan. Efektivitas kerja pengguna diukur menggunakan skala likert 1-4, dimana responden diberikan kebebasan untuk menentukan pendapat sesuai apa yang dialami dan dirasakan. Indikator dalam penelitiaan ini yaitu, optimisasi tujuan, ketepatan perhitungan biaya, kemampuan adaptasi, dan ketepatan perhitungan biaya.Variabel efektivitas kerja pengguna dalam penelitian ini diukur dengan Skala Likert yang memiliki nilai 4 poin, karena hal ini dilakukan untuk menghindari bias jawaban apabila menggunakan nilai 5 poin karena kemungkinan responden akan cenderung memilih jawaban netral apabila menemukan pernyataan atau pertanyaan yang meragukan bagi responden.

Variabel dependen (Y) adalah variabel yang dipengaruhi atau menjadi akibat dari variabel bebas atau independen Sugiyono (2014:59). Variabel dependen dalam penelitian ini adalah kinerja perusahaan.Kinerja perusahaan merupakan suatu gambaran tentang kondisi keuangan suatu perusahaan yang dianalisis dengan alat-alat analisis keuangan, sehingga dapat diketahui mengenai baik buruknya keadaan keuangan suatu perusahaan yang mencerminkan prestasi kerja dalam periode tertentu. Dimana pengukuran kinerja perusahaan diukur dengan Return on Sales (ROS). Variabel kinerja perusahaan dalam penelitian ini diukur dengan Return on Sales (ROS)karena jenis usaha pada usaha kecil dan menengah lebih identik pada sektor perdagangan atau penjualan yang berkaitan dengan pemasaran.

Data Kuantitatif merupakan data yang berbentuk angka-angka atau data-data kualitatif yang diangkakan Sugiyono (2014:14). Data kuantitatif dalam penelitian ini adalah jumlah UKM yang menggunakan e-commerce di Denpasar serta hasil 
ISSN: 2302-8556

E-Jurnal Akuntansi Universitas Udayana Vol.24.3.September (2018):1880-1907

kuesioner yang berupa jawaban responden yang diukur dengan variabel Dummy, ROS, dan skala Likert. Data Kualitatif merupakan data yang dinyatakan dalam bentuk kata, kalimat, dan gambar Sugiyono (2014:14). Data kualitatif dalam penelitian ini adalah daftar nama perusahaan UKM yang menggunakan $e$-commerce yang terdapat di Denpasar.

Data Primer merupakan data yang diperoleh langsung dari sumbernya, diamati, dicatat untuk pertama kalinya Sugiyono (2014:129). Data primer dalam penelitian ini yaitu berupa pernyataan responden dalam menjawab kuesioner pada perusahaan UKM yang menggunakan e-commercedi Denpasar.Data Sekunder yaitu data yang diperoleh secara tidak langsung melalui media perantara seperti orang lain dan dokumen Sugiyono (2014:129). Data sekunder dalam penelitian ini adalah data mengenai jumlah UKM yang menggunakan e-commerce di Denpasar yang datanya didapat dariDinas Perindustrian dan Perdagangan di Kota Denpasar serta refrensi yang terkait.

Menurut Sugiyono (2014:116), sampel adalah bagian dari jumlah dan karakteristik yang dimiliki oleh populasi. Dalam penelitian ini penulis menggunakan probability sampling dengan metode simple random sampling, yaitu metode penentuan sampel dengan pengambilan anggota sampel dari populasi dilakukan dengan cara diundi menggunakan nomor urut dalam daftar nama UKM yang menggunakan e-commerce di Denpasar tanpa memperhatikan strata yang ada dalam populasi itu. Cara demikian dilakukan bila anggota populasi dianggap homogen. 
Perhitungan pengambilan sampel dengan menggunakan rumus menurut Slovin Husein Umar (2008:263) sebagai berikut:

$\mathrm{n}=\frac{\mathrm{N}}{1+\mathrm{N}(\mathrm{e})^{2}}$

Keterangan:

$\mathrm{n}=$ Sampel

$\mathrm{N}=$ Populasi

$\mathrm{E}=$ Taraf Toleransi

Maka perhitungannya sebagai berikut:

$$
\begin{aligned}
\mathrm{n} & =\frac{766}{1+766(0,1)^{2}} \\
& =88,45
\end{aligned}
$$

Berdasarkan perhitungan sampel dengan rumus Slovin, maka dari 766 unit UKM yang menggunakan e-commerce di Denpasar jumlah sampel yang harus diteliti sebanyak 88 unit UKM.

Metode pengumpulan data yang digunakan dalam penelitian ini adalah dengan menggunakan kuesioner, yaitu metode pengumpulan data yang dilakukan dengan cara memberi seperangkat pertanyaan atau pernyataan tertulis kepada responden untuk dijawab Sugiyono (2014:199). Pada penelitian ini, kuesioner langsung diantarkan ke lokasi penelitian dan diberikan kepada responden. Kuesioner disebarkan berupa daftar pertanyaan maupun pernyataan tertulis kepada responden mengenai e-commerce dan efektivitas kerja pengguna terhadap kinerja perusahaan pada UKM di Denpasar. 
ISSN: 2302-8556

E-Jurnal Akuntansi Universitas Udayana Vol.24.3.September (2018):1880-1907

Dalam penelitian ini digunakan teknik analisis regresi linear berganda yang digunakan untuk memperoleh gambaran mengenai pengaruh variabel bebas terhadap variabel terikat dengan bantuan Software Statistical Package for Social Science (SPSS) for Windows. Analisis ini digunakan untuk menjawab bagaimana pengaruh $e$ commerce dan efektivitas kerja pengguna terhadap kinerja perusahaan pada usaha kecil dan menengah di Denpasar. Model regresi linear berganda ini dirumuskan sebagai berikut:

$$
\mathrm{Y}=\alpha+\beta_{1} \mathrm{X}_{1}+\beta_{2} \mathrm{X}_{2}+\mathrm{e}
$$

\section{Keterangan:}

Y : Kinerja Perusahaan

$\alpha \quad$ : Konstanta

$\mathrm{X}_{1} \quad$ : E-Commerce

$\mathrm{X}_{2} \quad$ : Efektivitas Kerja Pengguna

$\beta_{1} \quad$ : Koefisien Regresi Variabel $X_{1}$

$\beta_{2} \quad$ : Koefisien Regresi Variabel $X_{2}$

e : Error

\section{HASIL DAN PEMBAHASAN}

Untuk memperjelas dan mempermudah pemahaman atas hasil penelitian ini, akan dideskripsikan statistik dari masing-masing faktor yang menjadi variabel dalam penelitian ini. Statistik deskriptif dalam penelitian ini disajikan untuk memberikan informasi mengenai karakteristik variabel penelitian antara lain: nilai minimum, maksimum, rata-rata, dan deviasi standar dengan $\mathrm{N}$ adalah banyaknya responden penelitian. Hasil analisis deskriptif disajikan pada Tabel 1 berikut ini: 
Tabel 1

Hasil Statistik Deskriptif

\begin{tabular}{lccccc}
\hline & N & Minimum & Maximum & Mean & Std. Deviation \\
\hline KinerjaPerusahaan & 68 & 0,2148 & 0,4185 & 0,316090 & 0,0420394 \\
E-Commerce & 68 & 0,00 & 1,00 & 0,6029 & 0,49293 \\
Efektivitas Kerja Pengguna & 68 & 7,37 & 22,33 & 16,3569 & 5,09663 \\
Valid N (listwise) & 68 & & & & \\
\hline
\end{tabular}

Sumber : Data diolah, 2017

Berdasarkan Tabel 1 dapat dilihat bahwa jumlah pengamatan (N) dari penelitian ini adalah sebanyak 68. Nilai terendah dari data ditunjukan oleh skor minimum dalam tabel, sedangkan nilai tertinggi dari data ditunjukan oleh skor maximum. Mean digunakan untuk mengukur nilai rata-rata dari data, dan standar deviation menunjukan simpangan baku.

Variabel kinerja perusahaan mempunyai skor kisaran 0,2148-0,4185 dengan nilai minimum 0,2148 dan skor maximum 0,4185 sehingga diperoleh skor rata-rata sebesar 0,316090dan standar deviation sebesar 0,0420394. Hal ini berarti berdasarkan hasil statistik deskriptif, terjadi perbedaan nilai kinerja perusahaan yang diteliti terhadap nilai rata-ratanya sebesar0,0420394.

Variabel e-commerce mempunyai skor kisaran 0,00-1,00 dengan nilai minimum 0,00 dan skor maximum 1,00 sehingga diperoleh skor rata-rata sebesar 0,6029 dan standar deviation sebesar 0,49293. Hal ini berarti berdasarkan hasil statistik deskriptif, terjadi perbedaan nilai e-commerce yang diteliti terhadap nilai rata-ratanya sebesar 0,49293. 
ISSN: 2302-8556

E-Jurnal Akuntansi Universitas Udayana Vol.24.3.September (2018):1880-1907

Variabel efektivitas kerja pengguna mempunyai skor kisaran 7,37-22,33 dengan nilai minimum 7,37 dan skor maximum 22,33 sehingga diperoleh skor rata-rata sebesar16,3569 dan standar deviation sebesar 5,09663. Hal ini berarti berdasarkan hasil statistik deskriptif, terjadi perbedaan nilai efektivitas kerja penggunayang diteliti terhadap nilai rata-ratanya sebesar5,09663.

Uji validitas dan uji reliabilitas adalah uji yang dapat dilakukan sebelum data dianalisis lebih lanjut. Kedua uji ini dilakukan dengan tujuan untuk meyakinkan bahwa item-item instrumen penelitian dapat dikatakan valid dan reliabel. Kedua uji ini dilakukan saat hasil penelitian ini terkumpul, kemudian ditransformasikan menjadi data uji dalam bentuk interval.

Pengujian dilakukan dengan menghitung nilai pearson correlatation. Korelasi Pearson digunakan untuk mengukur ketepatan suatu item dalam kuesioner, dimana butir pernyataan dianggap valid apabila nilai Korelasi Pearson butir pernyataan dengan skor totalnya bernilai di atas 0,30 (Sugiyono, 2013:115). Tabel 2 menyajikan hasil uji validitas instrument penelitian sebagai berikut:

Tabel 2

Hasil Uji Validitas

\begin{tabular}{llll}
\hline Variabel & Instrumen & R & Keterangan \\
\hline & X2.1 & 0,827 & Valid \\
& X2.2 & 0,765 & Valid \\
Efektivitas Kerja Pengguna $\left(\mathrm{X}_{2}\right)$ & X2.3 & 0,906 & Valid \\
& X2.4 & 0,970 & Valid \\
& X2.5 & 0,904 & Valid \\
& X2.6 & 0,913 & Valid \\
\hline
\end{tabular}

Sumber: Data diolah, 2017 
Ni Made Werin Sarastyarini dan Ketut Yadnyana. Pengaruh...

Berdasarkan Tabel 2 dapat diketahui bahwa seluruh instrumen yang digunakan untuk mengukur variabel penelitian yaitu efektivitas kerja pengguna adalah valid. Hal ini dapat dilihat dari nilai masing-masing item pertanyaan yang memiliki nilai person correlation yang diperoleh lebih besar dari 0,30.

Uji realibilitas dilakukan untuk mengukur konsistensi dan stabilitas dari kuesioner. Suatu instrument dikatakan reliabel jika nilai croncbach's alpha lebih besar dari 0,60 (Ghozali,2006:33). Berdasarkan hasil dari Uji Reliabilitas penelitian ini dapat diketahui bahwa instrumen penelitian adalah realibel dan layak digunakan untuk mengumpulkan data karena variabel memiliki cronbach's alpha lebih besar dari 0,60. Cronbach's alpha lebih besar dari 0,60yaitu 0,943 menunjukan bahwa keseluruhan variabel layak digunakan untuk menjadi alat ukur instrumen kuesioner dalam penelitian ini.

Uji normalitas dilakukan untuk menguji apakah residual model regresi berdistribusi normal atau tidak dengan melakukan uji kolmogorov-smirnov. Data dikatakan berdistribusi normal apabila koefisien Asymp.Sig (2-tailed) lebih besar dari tingkat alpha, dimana $\alpha=0,05$. Berdasarkan hasil dari Uji Normalitas penelitian ini menunjukkan bahwa nilai Asymp. Sig. (2-tailed) sebesar 0,059. Hasil tersebut mengindikasikan bahwa efektivitas kerja pengguna tersebut berdistribusi normal karena nilai Asymp. Sig. (2-tailed)0,059lebih besar dari nilai alpha 0,05.

Uji multikolinearitas dilakukan untuk menguji apakah ditemukan adanya korelasi antar variabel bebas. Variabel dikatakan tidak terdapat multikolinearitas apabila nilai tolerance lebih dari 0,1 atau VIF kurang dari 10. Berdasarkan hasil dari 
ISSN: 2302-8556

E-Jurnal Akuntansi Universitas Udayana Vol.24.3.September (2018):1880-1907

Uji Multikolinearitas dalam penelitian ini bahwa nilai tolerance e-commerce adalah 0,771dan VIF dari variablee-commerceadalah 1,297. Untuk tolerance efektivitas kerja pengguna adalah 0,771 dan VIF dari variable efektivitas kerja pengguna adalah 1,297. Nilai dari kedua variable tersebut menunjukkan bahwa nilai toleranceuntuk setiap variabel lebih besar dari 0,10 dan nilai VIF lebih kecil dari 10 yang berarti model persamaan regresi bebas dari multikolinieritas.

Uji heteroskedastisitas bertujuan untuk menguji apakah dalam sebuah model moderasi terjadi ketidaksamaan varians dari residual atas satu pengamatan ke pengamatan yang lain. Untuk mendeteksi adanya heterokedastisitas pada penelitian ini menggunakan uji Gletser. Jika signifikan di atas 5\% maka disimpulkan model regresi tidak mengandung adanya heteroskedastisitas. Berdasarkan hasil dari Uji Heterokedastisitas didapatkan hasil perhitungan nilai signifikansi masing-masing variabel yang menunjukkan level sig $>\alpha(0,05)$ yaitu 0,714 untuk e-commerce (X1), dan 0,339 untuk efektivitas kerja pengguna(X2). Ini berarti model regresi yang digunakan dalam penelitian ini terbebas dari heterokedastisitas.

Pengujian ini bertujuan untuk menguji hubungan antara pengaruh variabel independen dengan dependen. Uji ini digunakan untuk mengetahui pengaruh $e$ commerce dan efektivitas kerja pengguna terhadap kinerja perusahaan pada usaha kecil dan menengah di Denpasar. Hasil pengujian dapat dilihat dalam tabel 3 berikut ini : 
Tabel 3

Hasil Uji Regresi Linear Berganda

\begin{tabular}{|c|c|c|c|c|c|}
\hline \multirow{2}{*}{ Model } & \multicolumn{2}{|c|}{$\begin{array}{l}\text { Unstandardized } \\
\text { Coefficients }\end{array}$} & \multirow{2}{*}{$\begin{array}{c}\begin{array}{c}\text { Standardized } \\
\text { Coefficients }\end{array} \\
\text { Beta }\end{array}$} & \multirow[t]{2}{*}{$\mathbf{t}$} & \multirow[t]{2}{*}{ Sig. } \\
\hline & B & $\begin{array}{l}\text { Std. } \\
\text { Error }\end{array}$ & & & \\
\hline (Constan) & 0,222 & 0,011 & & 19,695 & 0,000 \\
\hline E-Commerce & 0,025 & 0,008 & 0,291 & 3,219 & 0,002 \\
\hline Efektivitas Kerja Pengguna & 0,005 & 0,001 & 0,584 & 6,458 & 0,000 \\
\hline$F_{\text {hitung }}$ & & & 46,696 & & \\
\hline Sig. F Fitung & & & $\mathbf{0 , 0 0 0}$ & & \\
\hline $\mathbf{R}^{2}$ & & & $\mathbf{0 , 5 9 0}$ & & \\
\hline Adjusted $R^{2}$ & & & $\mathbf{0 , 5 7 7}$ & & \\
\hline
\end{tabular}

Sumber: Data diolah, 2017

$$
\mathrm{Y}=0,222+0,025\left(\mathrm{X}_{1}\right)+0,005\left(\mathrm{X}_{2}\right)+\mathrm{e}
$$

Nilai konstanta sebesar 0,222 berarti bahwa apabila variabel bebas yaitu $e$ commerce (X1), dan efektivitas kerja pengguna (X2) sama dengan nol, maka nilai kinerja perusahaan (Y)adalah sebesar 0,222.

Nilai Koefisien $\beta_{1}$ sebesar pada variabel e-commercesebesar 0,025. Koefisien regresi yang bernilai positif memiliki arti bahwa kinerja perusahan pada usaha kecil dan menengahakan semakin meningkat apabila pelaku usaha menggunakan $e$ commerce dalam menjalankan dan mengembangkan usahanya.

Nilai Koefisien $\beta_{2}$ sebesar pada variabel efektivitas kerja pengguna sebesar 0,005. Koefisien regresi yang bernilai positif memiliki arti bahwa peningkatan pada efektivitas kerja penggunae-commerce akan diikuti juga dengan peningkatan kinerja perusahaan pada usaha kecil dan menengah yang menggunakan e-commerce di Denpasar. 
ISSN: 2302-8556

E-Jurnal Akuntansi Universitas Udayana Vol.24.3.September (2018):1880-1907

Ghozali (2011:97) menyatakan bahwa penambahan jumlah variabel bebas pada model regresi akan meningkatkan tau $(\tau)$ menurunkan nilai error $(\varepsilon)$, oleh karena itu untuk mengetahui determinasi total pada model regresi linear berganda atau model regresi moderasi maka digunakan nilai Rsquare yang telah disesuaikan (adjusted) dengan nilai eror. Berdasarkan Tabel 3, dapat diketahui nilai adjusted $\mathrm{R}^{2}$ adalah 0,590 atau 59,0persen, ini artinya sebesar 59,0 persen variasi kinerja perusahaan dipengaruhi oleh model yang dibentuk oleh variabel e-commerce $\left(\mathrm{X}_{1}\right)$, efektivitas kerja pengguna $\left(\mathrm{X}_{2}\right)$, sedangkan sisanya 41,0 persen dijelaskan oleh variabel lain di luar model penelitian ini. Variabel lain yang dapat mempengaruhi kinerja perusahaan seperti Sumber Daya Manusia, keahlian/kemampuan di bidang teknologi, danprasarana teknologi yang kurang memadai.

Berdasarkan Tabel 7 dapat dilihat nilai F signifikan sebesar 0,000 yang lebih kecil dari nilai $\alpha=0,05$, hal ini menunjukkan bahwa seluruh variabel independen mampu memprediksi atau menjelaskan fenomena kinerja perusahaan pada UKM di Denpasar dan menunjukkan bahwa model yang digunakan pada penelitian ini adalah layak untuk diteliti.

Level of significant $(\alpha)$ yang digunakan adalah 5 persen $(0,05)$. Apabila tingkat signifikansi $t$ hitung lebih besar dari nilai $\alpha=0,05$ maka $\mathrm{H}_{0}$ diterima dan $\mathrm{H}_{1}$ ditolak. Sebaliknya jika tingkat signifikansi $t$ hitung lebih kecil dari atau sama dengan $\alpha$ $=0,05$ maka $\mathrm{H}_{0}$ ditolak dan $\mathrm{H}_{1}$ diterima. Nilai signifikansi variabel e-commerce adalah 0,002. Nilai sig 0,002 lebih kecil dari 0,05 maka $\mathrm{H}_{0}$ ditolak dan $\mathrm{H}_{1}$ diterima. Dapat disimpulkan variabel e-commerce berpengaruhterhadap kinerja perusahaan. 
Ni Made Werin Sarastyarini dan Ketut Yadnyana. Pengaruh...

Nilai $\beta_{1}=0,025$ menunjukkan arah positif yang sama dengan hipotesis, dimana variable $e$-commerce berpengaruh positif terhadap kinerja perusahaan.

Nilai signifikansi variable efektivitas kerja penggunaadalah 0,000. Nilai sig 0,000 lebih kecil dari 0,05 maka $\mathrm{H}_{0}$ ditolak dan $\mathrm{H}_{1}$ diterima. Dapat disimpulkan variable efektivitas kerja penggunaberpengaruh terhadap kinerja perusahaan. Nilai $\beta_{2}$ $=0,005$ menunjukkan arah positif yang sama dengan hipotesis, dimana variabel efektivitas kerja penggunaberpengaruh positif terhadap kinerja perusahaan.

Hasil uji hipotesis menunjukkan bahwa e-commerce berpengaruh positif terhadap kinerja perusahaan. Hal ini ditunjukkan dari nilai koefisien regresi variabel e-commerce yaitu 0,025 dengan signifikansi uji t sebesar 0,002 lebih kecil dari 0,05 yang artinyakinerja perusahan pada usaha kecil dan menengah akan semakin meningkat apabila pelaku usaha menggunakan e-commerce dalam menjalankan dan mengembangkan usahanya.Perkembangan e-commerce dicapai untuk memperbesar net income, hal ini terjadi dikarenakan e-commerce mengurangi biaya-biaya yang ada dalam proses penjualan contohnya biaya pemasaran. Model ekonomi berbasis internet mengalami pertumbuhan yang lebih efisien pada transaction cost level (Benjamin dan Wigand, 2000). Efisiensi lainnya berasal dari pemasaran dan iklan (Hoffmann et al., 1995). Eliminasi perantara (middleman) dalam saluran distribusi juga dapat memiliki dampak besar pada efisiensi pasar (Michalski, 1995). Walaupun net sales meningkat karena e-commerce, hal tersebut juga diimbangi dengan peningkatan ROS atau yang biasa disebut dengan profit margin. 
ISSN: 2302-8556

E-Jurnal Akuntansi Universitas Udayana Vol.24.3.September (2018):1880-1907

Hasil uji hipotesis menunjukkan bahwa efektivitas kerja pengguna berpengaruh positif terhadap kinerja perusahaan. Hal ini ditunjukkan dari nilai koefisien regresi variabel efektivitas kerja pengguna yaitu 0,005 dengan signifikansi uji t sebesar 0,000 lebih kecil dari 0,05 yang artinyapeningkatan pada efektivitas kerja penggunae-commerce akan diikuti juga dengan peningkatan kinerja perusahaan pada usaha kecil dan menengah yang menggunakan e-commerce di Denpasar. Hal ini menunjukan bahwa penilaian kinerja berhubungan dengan penyelesaian tugas-tugas tertentu, apakah berhasil atau gagal dicapai oleh pengguna/pegawai. Pencapaian ini juga perlu dikaitkan dengan perilaku dari pekerja selama proses penilaian. Kinerja yang semakin tinggi melibatkan kombinasi dari peningkatan efisiensi, peningkatan efektivitas, peningkatan produktivitas dan atau peningkatan kualitas (Goodhue dan Thompson, 1995).

Hasil penelitian ini didukung oleh Love dan Irani (2004) mengemukakan bahwa penggunaan e-commerce lebih efektif dalam membantu pengembangan UMKM untuk mengetahui manfaat dalam fungsi operasi, yaitu membantu untuk meningkatkan kinerja secara keseluruhan. Hal ini juga sesuai dengan hasil penelitian Karagozoglu dan Lindell (2004) yang menemukan bahwa E-commerce memiliki dampak positif pada pengembangan basis pelanggan sehingga dapat meningkatkan kinerja UMKM.Hasil ini semakin diperkuat oleh hasil penelitian Lesmono (2015) yang membuktikan bahwa penggunaan e-commerce di dalam transaksi bisnis ini menimbulkan reaksi pada diri pengguna atau pemakainya, yaitu berupa penerimaan maupun penolakan. Kesuksesan penerapan e-commerce sangat tergantung pada 
Ni Made Werin Sarastyarini dan Ketut Yadnyana. Pengaruh...

penerimaan oleh user sebagai pengguna e-commerce. Artinya semakin efektif kerja user maka akan smaakin baik kinerja UMKM dalam pengembangan usahanya. Yulimar (2006) menyatakan penggunaan e-commerce berpengaruh positif dan signifikan terhadap peningkatan kinerja UMKM yang dibuktikan dengan adanya peningkatan terhadap omzet penjulan dan keuntungan yang di dapat perusahaan setelah penggunaan e-commerce akibat adanya perluasan relasi atau jaringan usaha.

\section{SIMPULAN}

Berdasarkan hasil penelitian maka dapat ditarik kesimpulan bahwa E-commerce berpengaruh positif terhadap kinerja perusahaan. Semakin meningkat perkembangan e-commerce pada UKM maka kinerja perusahaan pada UKM akan semakin berkembang. Efektivitas kerja pengguna berpengaruh positif terhadap kinerja perusahaan. Semakin meningkat nilai efektivitas kerja pengguna pada UKM maka kinerja perusahaan pada UKM akan semakin berkembang.

Berdasarkan hasil kesimpulan diatas maka saran yang dapat diberikan adalah Peneliti membuktikan bahwa e-commerce dapat memberikan pengaruh positif terhadap kinerja perusahaan. Oleh karena itu, para pelaku usaha sebaiknya menggunakan e-commerce dalam menjalankan bisnisnya karena dalam UKM penjualan adalah nomor satu. Media internet yang sebaiknya digunakan dalam $e$ commerce pada perusahaan adalah website dengan status pemanfaatan sebagai Website Integrasi yang artinya website yang manampilkan penawaran, pembelian, pembayaran dan integrasi dengan back office. Jika menggunakan website integrasi 
ISSN: 2302-8556

E-Jurnal Akuntansi Universitas Udayana Vol.24.3.September (2018):1880-1907

dalam e-commerce,pemasaran dapat lebih luas dan akan lebih mudah dalam melayani customer dalam negeri maupun luar negeri sehingga dapat meningkatkan penjualannya. Peneliti juga membuktikan bahwa efektivitas kerja pengguna memberikan pengaruh positif terhadap kinerja perusahaan. Oleh karena itu, para pekerja pengguna e-commerce sebaiknya efektif dalam menjalankan tugas dengan cara menerapkan kualitas kerja, kuantitas kerja, ketepatan waktu dan target penjualan perusahaan.

\section{REFERENSI}

Benjamin, \& Wigand. 1995. Electronic Markets and Virtual Value Chains on the Information Superhighway.Sloan Management Review, 62-72.

Bhuono Agung, Ngroho. 2005. Strategi Jitu Memilih Metode Statistik Penelitian dengan SPSS. Yogyakarta: ANDI. 48-64.

Departemen Koperasidan UKM, 2010.Sandingan Data Usaha Mikro Kecil dan Menengah Tahun 2005-2009, Jakarta.

Djaali, 2008.SkalaLikert. Jakarta: PustakaUtama. 148-162.

Efraim Turban, Jae Lee, 2000. Electronic Commerce: A Managerial Perspective, Prentice Hall, Inc, New Jersey, 203-207.

Eriksson, L. T., J. Hultman, and L. Naldi. 1999. "Small Business E-Commerce Development in Sweden an Emperical Study". International Journal of Business, Journal of Small in Business and Enterprise Development 15 (3), 555-570.

Ghozali, Imam. 2013. "Aplikasi Analisis Multivariate dengan Program IBM SPSS 20”. Semarang : UNDIP. 95-121.

Handayani, Rini. 2007, "Analisis Faktof-Faktor yang Mempengaruhi Minat Pemanfaatan Sistem Informasi”. SNA X. UNHAS Makasar 27-28 Juli. STIE Atma Bhakti Surakarta. 
Hoffmann, D. L., T. P. Novak, M. Peralta. 1999. Building Consumer Trust Online.Comm,ACM42(4) 80-85.

Husein, Umar. 2008. Metode Penelitian Untuk Skripi dan Tesis Bisnis. Jakarta. PT Raja grafindo Persada. 263.

Jumaili, Salman. 2005. “Kepercayaan Terhadap Teknologi Sistem Informasi Baru Dalam Evaluasi Kinerja Individual”. Kumpulan Materi Simposium Nasional Akuntansi VIII. Solo 15-16 September. 245-255.

Khan, M. R., \& Motiwalla, L., 2002. The influence of E-commerce initiatives on corporate performance: An empirical investigation in the United States. International Journal of Management, XIX (3), 503-510.

Karagozoglu, N. danLindell, M. 2004. Electronic Commerce Strategy, Operations, And Performance In Small Medium-Sized Enterprises. Journal of Small Business and Enterprise Development. 11(3), pp: 290-301.

Kraemer, K. L., Gibbs, J., \&Dedrick, J. 2002.Impact of Globalization on ECommerce Adoption and Firm Performance: A Cross-Country Investigation. Irvine: University of California, 250-255.

Lesmono, Ibnu Dwi. 2015. Pengaruh Penggunaan E-Commerce Bagi Pengembangan Usaha Kecil Menengah (Ukm) DenganPendekatan Technology Acceptance Model. Evolusi. 3(1), h: 49-60.

Laudon, K.C,.\& Laudon, J.P. 2011.Management Information Systems: Managing the Digital Firm (12 ${ }^{\text {th }}$ ed.). New Jersey: Pearson Prentice Hall. 60-72.

Love, P.E.D. danIrani, Z. 2004. An Exploratory Study Of Information Technology Evaluation And Benefits Management Practices Of SMEs In The Construction Industry. Information \& Management, 42 (1), pp. 227-242.

Maksoud, S.S.A., \& Youssef, M.A.A. 2003.Information and Communication Technology for Small and Medium Enterprises in Egypt (Case Study).Cairo: SME Development Unit Ministry if Foreign Trade Egypt.50-65.

Mamduh. M. Hanafi. 2003. Analisis Laporan keuangan, Penerbit UPP AMKYKPN, Yogyakarta.

Miles, M.B., and A.B. Huberman. 1994. Qualitative Data Analysis A Sourcebook of New Methods. Newbury Park, CA. Sage. 277-311. 
ISSN: 2302-8556

E-Jurnal Akuntansi Universitas Udayana Vol.24.3.September (2018):1880-1907

Munawir, 1995, Analisis Laporan Keuangan, Edisi Keempat Cetakan Kelima, Liberty Jogya, Yogyakarta. 211-230.

Naranjo-Gil, D. (2004). The Role of Sophisticated Accounting System in Strategy Management1. The International Journal of Digital Accounting Research, IV (8), 125-244.

Partomo, T.S dan Soejoedono, A.R.2004. Ekonomi Skala Kecil/Menengah dan Koperasi.Galia Indonesia : Bogor. 178,185.

Rainer, R.K.,\& Cegielski, C.G.,2011.Introduction to Information Systems: Supporting and Transforming Business ( $3^{\text {rd }} \mathrm{ed}$.). United States: John Wiley \& Sons. 55-63.

Robbins, Stephen P. and Coulter,Mary. 2012. Management. New Jersey: Pearson Education, Inc.

Saeed, K. A., Grover, V., \& Hwang, Y. (2005). The Relationship of E-Commerce Competence to Customer Value and Firm Performance: An Empirical Investigation. Journal of Management Information Systems, XXII (1), 223256.

Sanjaya, Wina. 2014. Strategi Pembelajaran; BerorientasiStandar Proses Pendidikan.KencanaPrenada Media Grup. Jakarta. 256.

Senn, J., 2000. Business-to-Business E-Commerce.Information System Management, 23-32.

Sudarmanto, R.Gunawan. (2005). Ananlisis Regresi Linear Ganda dengan SPSS. Grahallmu. Yogyakarta. 130-142.

Sugiyono, 2014.MetodePenelitianKuantitatif, Kualittatifdan R\&D. Bandung: Alfabeta. 234.

Sutaryo, 2004. PengaruhKarakteristikInovasiterhadapAdopsiTeknologi Internet olehUMKM.JournalekonomidanKeuangan , II (2), 290.

Venkatesh, V., Morris, M. G., Davis, G. B., dan Davis, F. D.2003. User Acceptance of Information Technology: Toward a Unified View. MIS Quarterly, 27(3), 425-478. 
Ni Made Werin Sarastyarini dan Ketut Yadnyana. Pengaruh...

Wang, Y. dan Ahmed, P.K. (2009). The moderating effect of the business strategic orientation on e-commerce adoption: evidence from UK family run SMEs. Journal of Strategic Information Systems.

Yulimar, Vidi Arini, 2006, Analisis Faktor-faktor Yang Mempengaruhi Pengadopsian Electronic Commerce dan Pengaruhnya Terhadap Kinerja Perusahaan (Studipada Perusahaan Kecil danMenengah di Indonesia Tesis. Program Studi Magister ManajemenUniversitasDiponegoro. 342-334.

Zuhal, 2010. Knowledge and Innovation Platform Kekuatan Daya Saing.Jakarta:Gramedia. 222. 